\title{
Zmiany potencjału ekonomicznego wybranych korporacji informatycznych w warunkach kryzysu gospodarczego
}

\author{
Changes in the economic potential of selected information \\ technology corporations in a context of economic crisis
}

\begin{abstract}
Streszczenie: Korporacje informatyczne w okresie kryzysu, podobnie jak firmy innych branż, reagowały na zmieniające się warunki w zróżnicowany sposób. Przeprowadzone badania wskazują, że w latach 2003-2011 można wyróżnić tzy okresy rozwoju korporacji informatycznych: lata wzrostu gospodarczego (2003-2007), lata kryzysu (2007-2009) oraz okres ponownego wzrostu (2009-2011). Przedmiotem niniejszych rozważań będą wybrane korporacje informatyczne reprezentujące zróżnicowane rodzaje działalności informatycznej. Szczegółową analizą objęto dziewięć korporacji: Amazon. com, Apple, Ericsson, Google, IBM, Microsoft, Motorola, Nokia oraz Panasonic. W badaniach zmierzano do analizy i oceny zmian potencjału ekonomicznego tych wybranych korporacji.
\end{abstract}

\begin{abstract}
During the economic crisis, similarly to companies from other sectors, IT corporations varied in terms of their reactions to the transforming environment.

According to research, between 2003 and 2011, 3 different phases of development in the sector can be identified: the economic growth (2003-2007), the crisis (2007-2009) and the phase of repeated growth (2009-2011).

The paper focuses on a pool of IT corporations operating in different areas of IT. The author chose to focus on 9 corporations (Amazon.com, Apple, Ericsson, Google, IBM, Microsoft, Motorola, Nokia, Panasonic) to analyse and assess changes in their economic potential.
\end{abstract}

Słowa kluczowe: korporacje informatyczne; kryzys; potencjał ekonomiczny; wartość aktywów; wartość rynkowa; wartość sprzedaży; wartość zysków

Keywords: information technology corporations; crisis; economic potential; assets; market value; sales; profits 


\section{WSTĘP}

W wyniku nasilającego się procesu koncentracji kapitału korporacje ponadnarodowe odznaczają się coraz większym potencjałem ekonomicznym, który niekiedy znacznie przewyższa potencjał gospodarczy poszczególnych krajów. Kapitał korporacji, wyrażany m.in. wartością rynkową, wartością majątku, zysku czy sprzedaży, określa ich pozycję w gospodarce światowej, krajowej i regionalnej. Zasoby kapitałowe korporacji pozwalają bowiem na podejmowanie przez nie różnych działań związanych np. z pracami inwestycyjnymi, zakupami czy przejęciami innych firm, zmianami działalności produkcyjnej czy usługowej, lub podnoszeniem jakości kadry pracowniczej. Korporacje światowe poszukują nowych, efektywnych lokalizacji (Dorocki, 2010; Kilar, 2014) i często w zasadniczym stopniu dyktują warunki funkcjonowania firm na terenie poszczególnych krajów i regionów (Zioło, 2009).

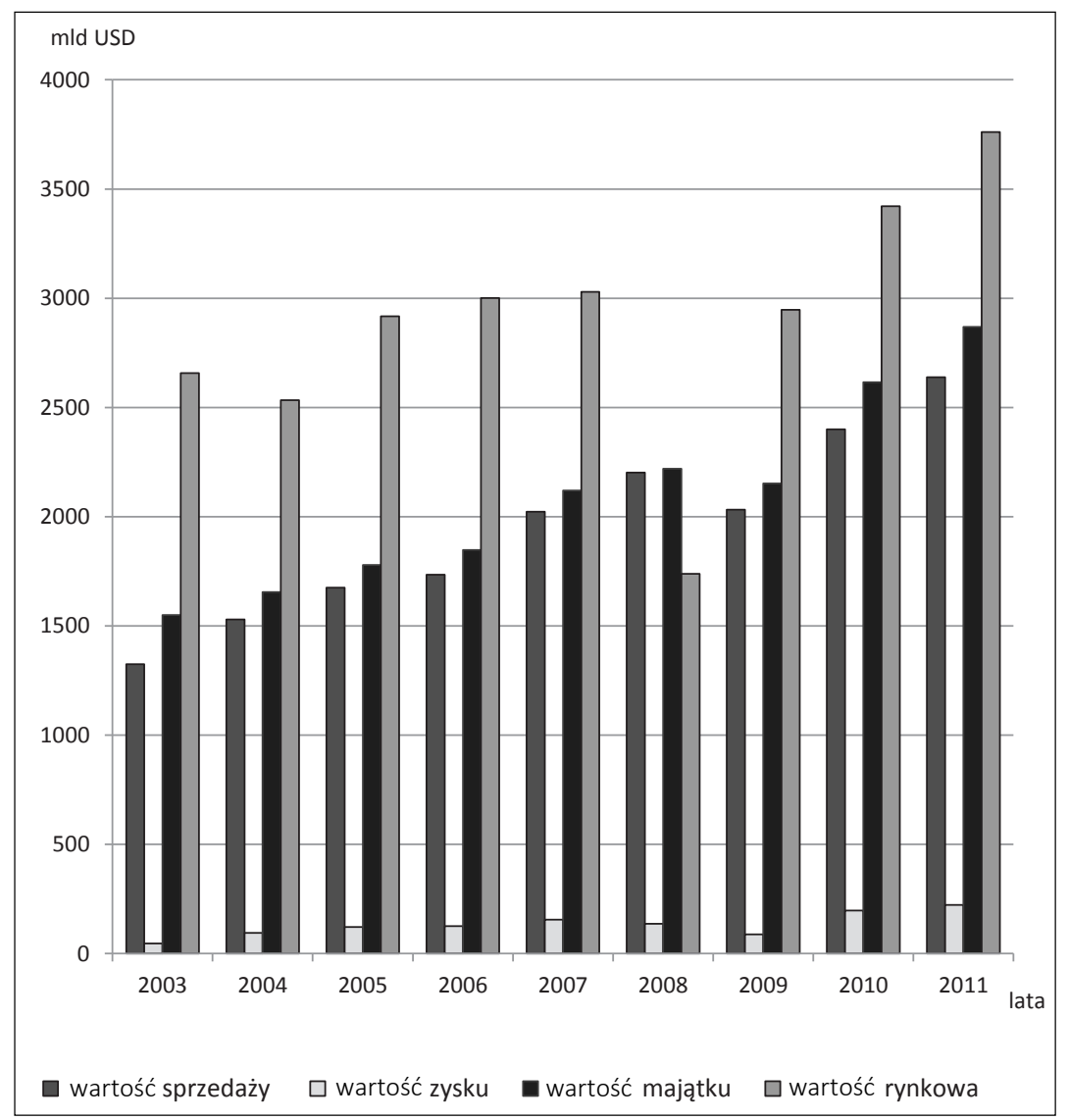

Ryc. 1. Zmiany wartości potencjału ekonomicznego dominujących korporacji informatycznych w latach 2003-2011

Źródło: opracowanie własne na podstawie raportów rocznych badanych korporacji 
Wśród największych korporacji światowych znaczącą rolę odgrywają korporacje sektora informatycznego (Kilar, 2009a), które w latach 2003-2011 charakteryzowały się znaczną dynamiką potencjału ekonomicznego. Łączna wartość sprzedaży (sales) ${ }^{1} 100$ dominujących korporacji tego sektora zwiększyła się w tym okresie z 1,3 bln USD do 2,6 bln USD, czyli do 199,2\%, wartość ogólnego zysku (profits) wahała się od 47,1 mld USD do 222,8 mld USD, czyli do 473,3\%, wartość aktywów (assets) oscylowała od 1,5 bln USD do 2,9 bln USD, czyli do $185,0 \%$, a wartość rynkowa (market value) wzrosła z 2,6 bln do 3,8 bln USD, czyli do $141,5 \%$ (ryc. 1, tab. 1).

Tab. 1. Zmiany potencjału ekonomicznego dominujących korporacji informatycznych w latach 20032011 (w mld USD)

\begin{tabular}{|c|c|c|c|c|c|c|c|c|}
\hline \multirow{2}{*}{ Lata } & Wartość & Wartość & Wartość & Wartość & \multicolumn{4}{|c|}{ Dynamika $(2003=100 \%)$} \\
\hline & \multicolumn{4}{|c|}{ w mld USD } & sprzedaży & zysku & aktywów & $\begin{array}{l}\text { wartości } \\
\text { rynkowej }\end{array}$ \\
\hline 2003 & 1324,9 & 47,1 & 1550,5 & 2658,0 & 100,0 & 100,0 & 100,0 & 100,0 \\
\hline 2004 & 1529,5 & 94,3 & 1655,2 & 2533,8 & 115,4 & 200,4 & 106,8 & 95,3 \\
\hline 2005 & 1675,1 & 121,6 & 1779,3 & 2916,9 & 126,4 & 258,3 & 114,8 & 109,7 \\
\hline 2006 & 1734,5 & 125,6 & 1847,2 & 3000,9 & 130,9 & 266,8 & 119,1 & 112,9 \\
\hline 2007 & 2022,2 & 154,9 & 2120,0 & 3029,1 & 152,6 & 329,2 & 136,7 & 114,0 \\
\hline 2008 & 2202,5 & 136,7 & 2219,3 & 1738,4 & 166,2 & 290,5 & 143,1 & 65,4 \\
\hline 2009 & 2032,6 & 87,9 & 2151,6 & 2947,5 & 153,4 & 186,7 & 138,8 & 110,9 \\
\hline 2010 & 2399,8 & 196,8 & 2616,1 & 3421,2 & 181,1 & 418,1 & 168,7 & 128,7 \\
\hline 2011 & 2639,1 & 222,8 & 2868,3 & 3761,0 & 199,2 & 473,3 & 185,0 & 141,5 \\
\hline
\end{tabular}

Źródło: opracowanie własne na podstawie raportów rocznych badanych korporacji

Poszczególne cechy potencjału ekonomicznego dominujących korporacji informatycznych charakteryzowały się w badanym okresie dużą zmiennością, która wynikała ze zmieniającej się koniunktury na rynku światowym, związanej z pojawiającym się kryzysem gospodarczym. Na podstawie dynamiki wartości analizowanych cech w latach 2003-2011 wyróżniono trzy okresy rozwoju, charakteryzujące się różną tendencją zmian. Pierwszy okres obejmuje lata 2003-2007 cechujące się wzrostem gospodarczym, drugi okres to lata 2007-2009 odznaczające się pojawiającym kryzysem, zaś trzeci to okres ponownego wzrostu w latach 2009-2011 (ryc. 2).

\footnotetext{
${ }^{1}$ Wartości sprzedaży, zysków i aktywów za lata 2003-2011 zostały zaczerpnięte z rankingów sporządzonych przez „Forbes” The Global 2000 z lat 2004-2012, które zostały zweryfikowane na podstawie raportów rocznych korporacji, zaś wartości rynkowe na dany dzień (szczegółowo omówione we wstępie) pochodzą z rankingów The Global 2000 oraz Global 1000.
} 


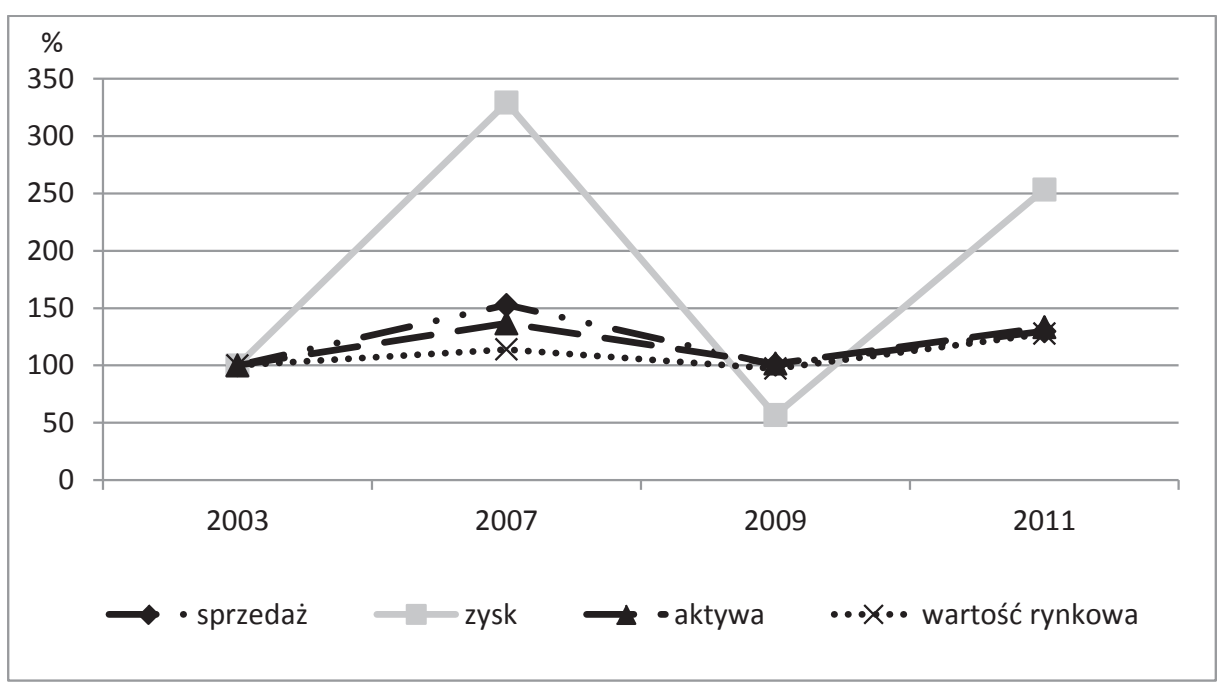

Ryc. 2. Dynamika zmian potencjału ekonomicznego dominujących korporacji informatycznych w latach 2003-2011

Źródło: opracowanie własne na podstawie raportów rocznych badanych korporacji

W wyróżnionych okresach potencjał ekonomiczny w świetle analizowanych cech wykazuje różne tendencje przemian (tab. 1). Najbardziej zróżnicowaną dynamiką odznaczała się wartość zysku, która w pierwszym okresie zwiększyła się do 329,2\%, a następnie w drugim okresie spadła do $56,7 \%$, po czym w trzecim okresie ponownie znacznie wzrosła do 253,6\%. Mniejszą zmiennością charakteryzowała się wartość rynkowa, która w pierwszym okresie wykazywała największą stabilność i wzrosła do 114,0\%, po czym zmniejszyła się i ponownie zwiększyła do $223,5 \%$. W analizowanym czasie podobnymi tendencjami charakteryzowały się wartości aktywów i sprzedaży, które równocześnie odznaczały się najmniejszą zmiennością. Generalnie wystąpiły tu stosunkowo niewielkie wahania wartości.

W świetle przedstawionej analizy zaznacza się różny stopień zróżnicowania potencjału ekonomicznego korporacji informatycznych, który w zależności od analizowanej cechy w różnym stopniu reagował na kryzys ekonomiczny.

Zatem kryzys gospodarczy w przestrzeni światowej wpłynął na zmianę uwarunkowań funkcjonowania i rozwoju przedsiębiorstw, w tym badanych korporacji. Jednak w zróżnicowany sposób poszczególne korporacje informatyczne objęte badaniami zareagowały na sytuację kryzysową, podjęły różne działania, by jej przeciwdziałać i odmienny był ich efekt.

W świetle powyższych przesłanek przedmiotem niniejszych rozważań będą wybrane korporacje informatyczne reprezentujące zróżnicowane rodzaje działalności informatycznej, takie jak: programowanie i oprogramowanie, sprzęt łączności, sprzęt komputerowy, serwis komputerów (usług komputerowych), sprzedaż internetowa i katalogowa, elektronika konsumencka. Przy wyborze korporacji do szczegółowych studiów przyjęto także takie kryteria, jak: okres powstania korporacji, czasookres podejmowania działalności informatycznej oraz lokalizacja 
siedziby zarządu w przestrzeni światowej. Szczegółową analizą objęto dziewięć korporacji: Amazon.com, Apple, Ericsson, Google, IBM, Microsoft, Motorola, Nokia oraz Panasonic.

$\mathrm{W}$ badaniach zmierzano do analizy i oceny zmian potencjału ekonomicznego wybranych korporacji informatycznych na tle 100 dominujących korporacji informatycznych, ze szczególnym uwzględnieniem okresu kryzysu gospodarczego.

\section{ZMIANY WARTOŚCI MIERNIKÓW POTENCJAŁU EKONOMICZNEGO BADANYCH KORPORACJI}

Wartość sprzedaży to jeden z mierników pojawiających się w rachunku zysków i strat, który jest częścią sprawozdania finansowego korporacji. Potencjał ekonomiczny wyrażony wartością sprzedaży analizowanych korporacji charakteryzuje się różnymi tendencjami zmian, przejawiającymi się w systematycznym wzroście wartości sprzedaży lub zmiennej dynamice. Systematycznym wzrostem wartości wyróżniały się Apple, Amazon.com, Google i Microsoft (ryc. 3), zaś zróżnicowaną dynamiką wartości sprzedaży cechowały się korporacje: Ericsson, Panasonic, Motorola i Nokia (Kilar, 2009b; Kilar, 2010; Kilar, 2011; Kilar, 2012).

Na dynamikę wartości sprzedaży analizowanych korporacji wpływało w początkowych latach nasilanie procesów informatyzacji przedsiębiorstw i instytucji, które stworzyły chłonne rynki. W miarę wypełniania rynków obserwowano wolniejsze tempo wzrostu sprzedaży. Zróżnicowanie wartości tego miernika zaznaczyło się w latach kryzysu, w których nastąpiło załamanie wartości sprzedaży w korporacji IBM, Panasonic, Nokia, Microsoft i Motorola. Związane to było z kurczącym się rynkiem na oferowane produkty w wyniku ograniczenia działalności produkcyjnej przemysłu, usług i instytucji. Niewielki wzrost sprzedaży zaznaczył się w okresie wychodzenia z kryzysu w latach 2010-2011, w którym niemalże wszystkie korporacje zwiększyły wartość sprzedaży. Jedna z analizowanych korporacji - Amazon.com - nie zareagowała na sytuację kryzysową. Można więc wnosić, że wzrost wartości sprzedaży korporacji w podstawowym stopniu zależy od nowoczesnych systemów produkcyjnych, usługowych i organizacyjnych oraz dążenia do podniesienia swojej sprawności.

Innym miernikiem, który ma istotne znaczenie dla korporacji, jest wartość osiąganych zysków. Zyski bowiem pozwalają na podejmowanie działalności modernizacyjnej i inwestycyjnej oraz zwiększanie wartości aktywów. Biorąc pod uwagę dynamikę zysku, możemy wyróżnić korporacje odznaczające się systematycznym wzrostem zysków, stagnacją, wahaniami oraz zmniejszaniem się wartości ich zysków (ryc. 4).

Do pierwszej grupy, charakteryzującej się systematycznym wzrostem zysków w analizowanym okresie, należą: Apple, Google, IBM i Microsoft. Na przykład korporacja Apple w latach 2003-2011 cechowała się wzrostem zysków z 0,1 mld USD do 33,0 mld USD, czyli 330-krotnym.

Stagnacja zysków w analizowanym okresie cechowała korporację Amazon.com, która na początku działalności miała wyniki działalności na granicy zysku, lecz w miarę postępującego procesu rozwoju wykazywała dodatnie wyniki finansowe. 


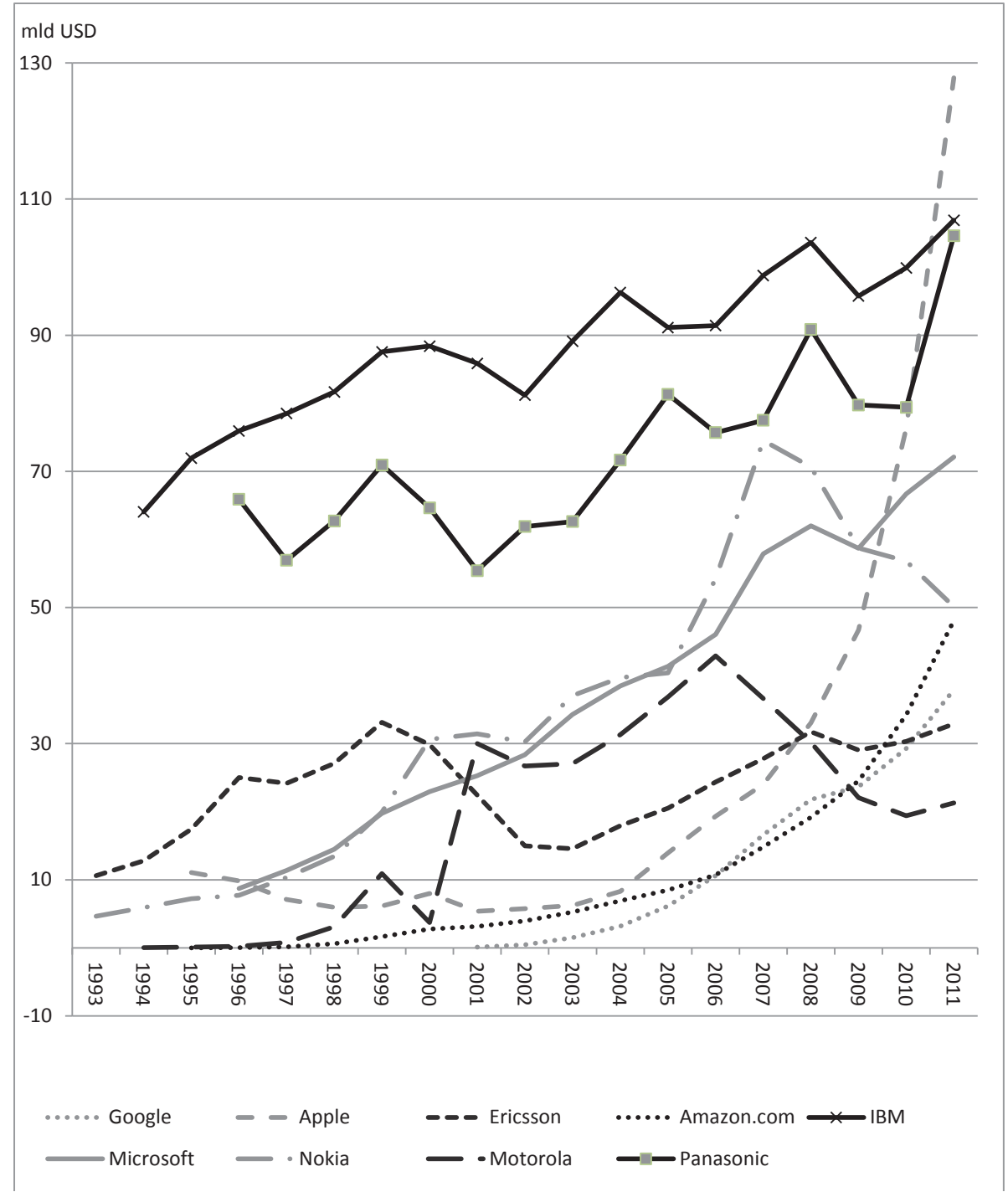

Ryc. 3. Zmiany wartości sprzedaży korporacji informatycznych w latach 1993-2011

Źródło: opracowanie własne na podstawie raportów rocznych badanych korporacji

Natomiast do korporacji o zmiennych wartościach zysków należą: Ericsson, Panasonic i Motorola. W latach 2000-2011 Motorola odznaczała się dużymi wahaniami wyników działalności, od -3,9 mld USD straty do 4,6 mld USD zysku. Skutki problemów na rynku informatycznym na przełomie wieków korporacja zaobserwowała w 2001 roku, gdy zyski nagle spadły z 1,3 mld do -3,9 mld USD. Deficyt utrzymywał się do 2002 roku, w którym wyniósł $-2,5$ mld USD. Kolejne lata cechowały się wzrostem wyników z prowadzonej działalności 
do 4,6 mld USD w 2005 roku, a następnie nagłym ich spadkiem do -4,2 mld USD w 2008 roku i stopniowym wzrostem do 1,0 mld USD w 2011 roku.

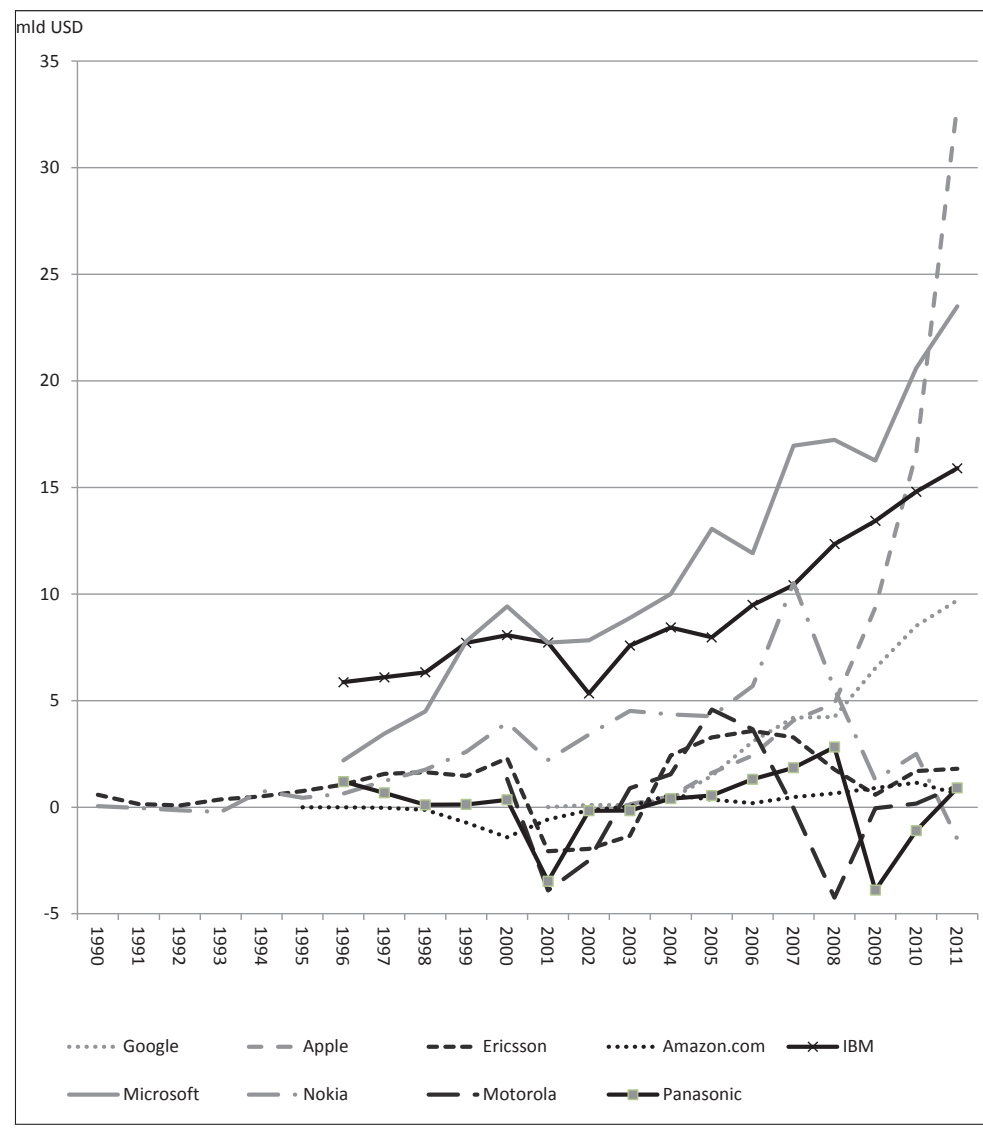

Ryc. 4. Zmiany wartości zysków osiąganych przez analizowane korporacje informatyczne w latach 1993-2011

Źródło: opracowanie własne na podstawie raportów rocznych badanych korporacji

Recesyjnymi tendencjami zysków odznaczała się korporacja Nokia, której wyniki finansowe zmniejszyły się ze 100 mln USD w 1990 roku do -1,5 mld USD straty w 2011 roku.

Przeprowadzona analiza wskazuje również, że najwyższymi zyskami w badanym okresie charakteryzowały się korporacje Apple (do 33,0 mld USD), Microsoft (do 23,5 mld USD) oraz IBM (do 15,9 mld USD), zatem korporacje o stabilnej i ugruntowanej pozycji na rynku informatycznym, reprezentujące różne rodzaje działalności. Korporacje te w żadnym roku analizowanego okresu nie zanotowały strat, mimo załamania rynku informatycznego w roku 2001 i kryzysu gospodarczego na świecie po 2007 roku. Najbardziej sytuacje kryzysowe zarówno pęknięcie bańki internetowej, jak i światowy kryzys gospodarczy - zaznaczyły się w wynikach korporacji Motorola, Panasonic i Ericsson, w których z ich powodu nastąpiły 
największe straty. Zatem na wyniki działalności badanych korporacji informatycznych najwyższy wpływ miała umiejętność zachowania się w sytuacjach trudnych (kryzysowych) i przyjęte w związku z nimi strategie działania.

Następnym miernikiem określającym potencjał badanych korporacji jest wartość gromadzonych przez nie aktywów, nazywanych niekiedy majątkiem. Uwzględniając zmiany wartości aktywów, podobnie jak w przypadku wartości zysków, wyróżniamy korporacje o tendencjach wzrostu, stagnacji, recesji oraz o zmiennych tendencjach (ryc. 5).

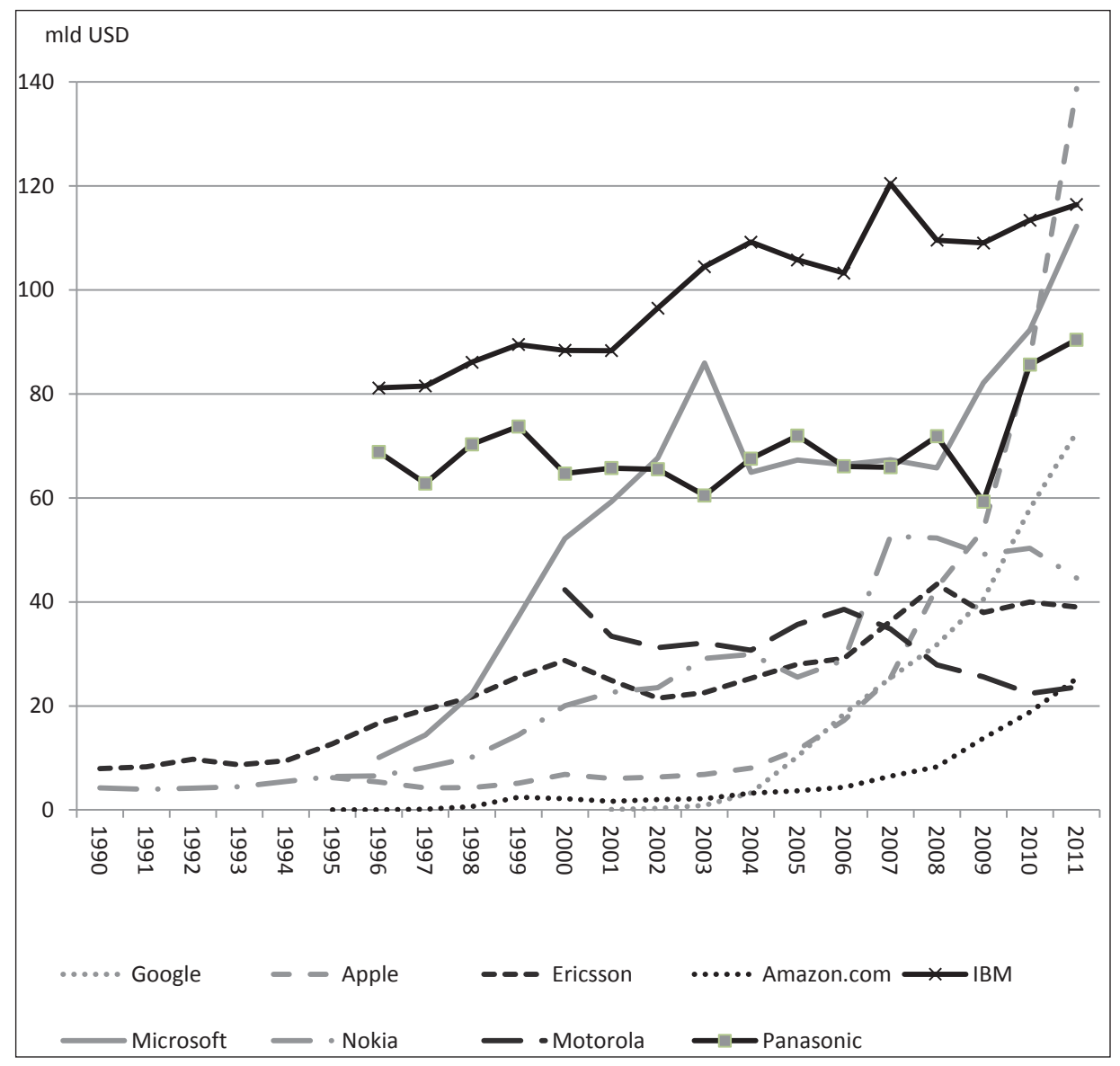

Ryc. 5. Zmiany wartości aktywów analizowanych korporacji informatycznych w latach 1993-2011

Źródło: opracowanie własne na podstawie raportów rocznych badanych korporacji

Pod względem dynamiki wartości aktywów do korporacji o stałym systematycznym wzroście należą: Google, Apple, Ericsson i Amazon.com.

Na przykład korporacja Apple w latach 1995-2011 cechowała się wzrostem wartości aktywów z 6,2 mld USD w 1995 roku do 138,7 mld USD w 2011 roku, czyli ponad 
dwudziestodwukrotnym, a skutki światowego kryzysu gospodarczego nie wpłynęły znacząco na zmiany wartości tego miernika.

Do korporacji o tendencjach do stagnacji wartości aktywów należą: Panasonic i IBM. Przykładowo wartość aktywów korporacji IBM w latach 1996-2011 wzrosła z 81,1 mld USD do 116,4 mld USD, czyli do 143,5\%, przy czym w okresie kryzysu światowego zanotowano stagnację wartości aktywów na poziomie ok. 109 mld USD. Również dynamika zmian była bardzo wyrównana w całym okresie, gdyż wartość rocznych indeksów dynamiki wahała się od $90,9 \%$ do $116,7 \%$.

Natomiast wahania wartości aktywów cechowały korporacje Microsoft i Nokia. Na przykład wartości miernika w korporacji Microsoft w latach 1996-2011 wahały się od 10,1 mld USD do 112,2 mld USD. W latach 1996-2003 następował szybki wzrost wartości aktywów z 10,1 mld USD do 85,9 mld USD, czyli do 850,5\%, przy łańcuchowych indeksach dynamiki od 113,6\% do 166,2\%. W 2004 roku, ze względu na karę nałożoną przez Komisję Europejską na korporację, wartość aktywów Microsoftu spadła do 64,9 mld USD, czyli o 21,0 mld USD (do 75,6\%). W latach 2005-2008 wystąpiły wahania od 65,8 mld USD do 67,3 mld USD, a w kolejnych latach następował ich szybki wzrost do 112,2 mld USD w 2011 roku. Zatem nastąpiło niemalże podwojenie wartości aktywów w okresie od 2004 roku, mimo że na świecie miał miejsce kryzys gospodarczy, któremu Microsoft się oparł, m.in. przez niezgodne z prawem europejskim działania monopolistyczne.

Recesyjny charakter miały aktywa korporacji Motorola, gdyż ich wartość w latach 2000-2011 spadła z 42,3 mld USD do 23,6 mld USD, czyli do 55,8\%.

Najwyższa wartość aktywów gromadzonych przez analizowane korporacje, podobnie jak w przypadku osiąganych wyników finansowych charakteryzowała korporacje Apple, Microsoft i IBM. Okres światowego kryzysu dla badanych firm cechował się stagnacją lub obniżeniem wartości majątku, lecz większość z nich szybko odbudowała straty wynikające z kryzysu. Nokia i Motorola, reprezentujące działalność: sprzęt łączności, mimo podjętych działań naprawczych w 2011 roku wciąż odczuwały skutki recesji, a ich aktywa nadal pozostały na niższym poziomie niż przed kryzysem.

\section{ZMIANY WARTOŚCI WSKAŹNIKÓW EKONOMICZNYCH}

Przedstawiona analiza dotyczyła zmian potencjału ekonomicznego objętych badaniem korporacji z określonych punktów widzenia. Zachodzi pytanie, w jakim stopniu wartości mierników potencjału wzajemnie na siebie wpływały.

W celu określenia efektywności korporacji informatycznych wykorzystano wskaźnik rentowności aktywów (ROA) i wskaźnik rentowności sprzedaży (ROS) oraz wskaźnik produktywności majątku. 
Wskaźnik rentowności majątku² dominujących korporacji informatycznych, obrazujący zdolność aktywów do generowania zysków, wynosił od 3,0 w 2003 roku do 7,8 w 2011 roku, co oznacza, że w tym okresie 1 USD zaangażowanych aktywów przyniósł korporacjom informatycznym średnio od 3,0 do 7,8 centów USD zysków (ryc. 6). Oznacza to, że wzrosła ponad dwukrotnie efektywność wykorzystania aktywów korporacji. Wskaźnik rentowności aktywów najpierw wzrastał w latach 2003-2005, a w kolejnym roku nastąpiła jego stagnacja na poziomie 6,8. W 2007 roku nieznacznie wzrósł do poziomu 7,3, a następnie wartość ROA zaczęła się zmniejszać i w 2009 roku osiągnęła wartość 4,1. W ostatnich dwóch latach badanego okresu wartość omawianego wskaźnika szybko zaczęła wzrastać i w 2011 roku wyniosła 7,8, czyli 1 USD zaangażowanych aktywów wygenerował 7,8 centów USD zysku. Zatem analiza wskaźnika ROA wykazała, że aktywa były coraz racjonalniej wykorzystywane w korporacjach informatycznych, przynosząc coraz większe zyski.

Wskaźnik rentowności sprzedaży ${ }^{3}$ dominujących korporacji informatycznych cechował się podobnymi tendencjami. W latach 2003-2011 wartości tego wskaźnika wahały się na podobnym poziomie jak wskaźnika rentowności aktywów, czyli od 3,6 do 8,4. Oznacza to, że 1 USD przychodów ze sprzedaży przyniósł od 3,6 centów USD do 8,4 centów USD zysków. W początkowym okresie następował szybki wzrost wartości wskaźnika i w 2005 roku wyniósł 7,3, następnie jego wartość nieznacznie się zmniejszyła do 7,2 i ponownie wzrosła do 7,7. W dwóch kolejnych latach, czyli 2008-2009, obserwowano spadek wartości ROS do 4,3 w 2009 roku, a w 2010 i 2011 roku ponowny szybki wzrost odpowiednio do 8,2 i 8,4.

Zatem potencjał ekonomiczny dominujących korporacji informatycznych w badanym okresie, wyrażony wskaźnikami rentowności, charakteryzował się znacznymi zmianami ich wartości. Ze względu na zmienne uwarunkowania funkcjonowania badanych korporacji zaobserwowano spadek wartości wskaźników rentowności majątku i rentowności sprzedaży w okresie kryzysu gospodarczego, który - jak wynika z przeprowadzonych badań - w dominujących korporacjach informatycznych zaznaczył się w latach 2007-2009. Należy podkreślić, że po 2009 roku wartości obydwu wskaźników znacznie wzrosły.

${ }^{2}$ Wskaźnik rentowności majątku, nazywany też wskaźnikiem zyskowności aktywów, ROA (return on total assets) obliczano za pomocą wzoru:

$R O A=$ zysk $\div$ aktywa $\times 100$.

Informuje on, ile zysku przyniósł 1 USD zaangażowanych aktywów.

3 Wskaźnik rentowności sprzedaży, nazywany też wskaźnikiem zyskowności sprzedaży, wskaźnikiem marży zysku oraz ROS (return on sales), obliczano za pomocą wzoru:

ROS $=$ zysk $\div$ sprzedaż $\times 100$.

Informuje on w niniejszej rozprawie, ile zysku otrzymały średnio korporacje z 1 USD przychodu ze sprzedaży. 


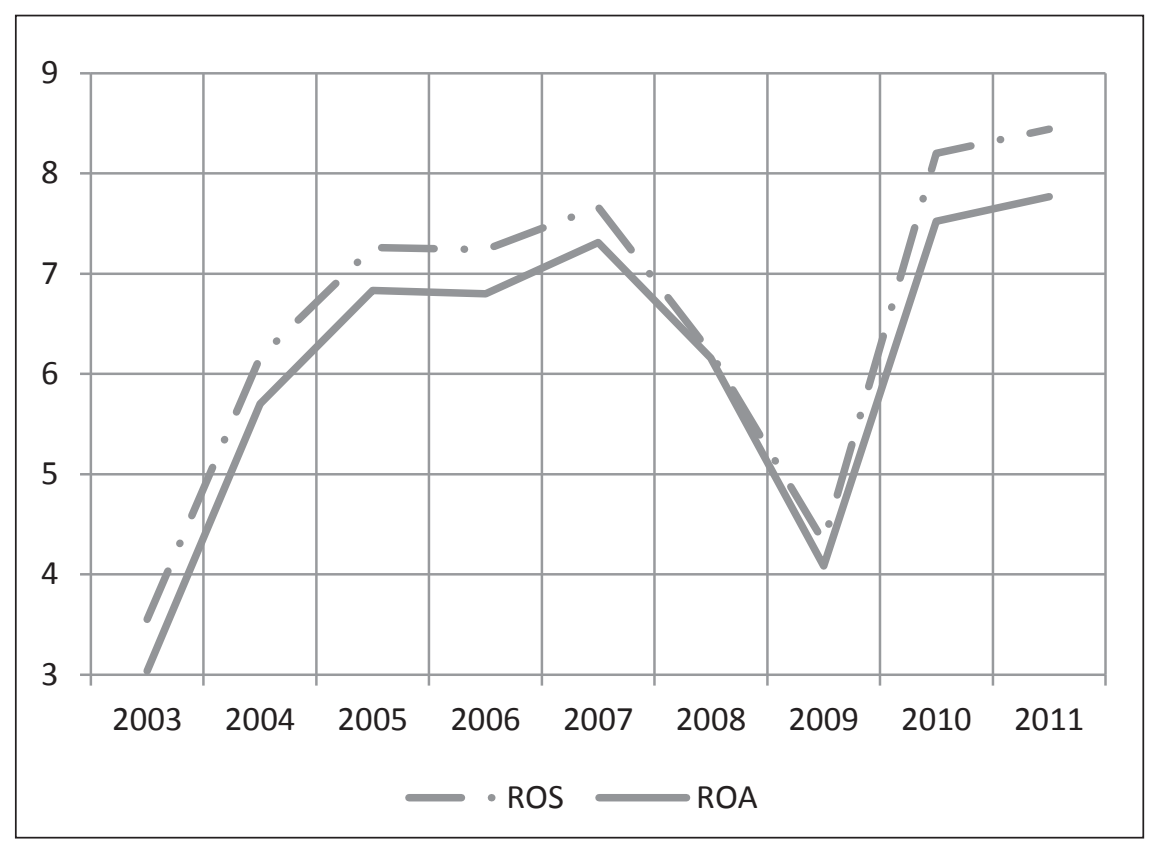

Ryc. 6. Zmiany wartości wskaźników rentowności sprzedaży (ROS) i rentowności aktywów (ROA) dominujących korporacji informatycznych w latach 2003-2011

Źródło: opracowanie własne na podstawie raportów rocznych badanych korporacji

Wskaźnik produktywności aktywów ${ }^{4}$, służący do oceny efektywności gospodarowania całkowitym majątkiem spółki, w latach 2003-2011 wahał się od 0,855 w 2003 roku do 0,992 w 2008 roku (ryc. 7). W okresie tym wartość wskaźnika ulegała znacznym zmianom. W latach 2003-2005 następował stały wzrost wartości wskaźnika, co oznacza, że korporacje informatyczne coraz efektywniej zarządzały swoim majątkiem, więc rosła wartość sprzedaży na jednostkę majątku. W 2006 roku korporacje te cechowały się nieco mniejszą zdolnością generowania przychodów z dysponowanych aktywów, gdyż wskaźnik wyniósł 0,939. W kolejnych trzech latach aktywa były ponownie efektywniej wykorzystywane, a wskaźnik stale wzrastał, do 0,992 w 2008 roku. W następnych latach nastąpiło załamanie w wyniku kryzysu światowego, a wartość wskaźnika zmniejszała się, do 0,917 w 2010 roku. Na wartość wskaźnika miało wpływ wiele czynników, wśród nich inwestycje podejmowane przez korporacje, sposób ich finansowania, a także kryzys gospodarczy na świecie i wynikająca $\mathrm{z}$ niego recesja również w działalności informatycznej. Należy zaznaczyć, że sprzedaż jest procesem ciągłym, natomiast inwestycje mają charakter skokowy, co wpływa na wartości analizowanych wskaźników. Poza tym, odwołując się do teorii międzynarodowego cyklu życia produktu oraz cyklu życia produktu nowoczesnego, wiadomo, że w różnych jego fazach sprzedaż ma różne tendencje. Przekłada się to na różną produktywność w poszczególnych

${ }^{4}$ Wskaźnik produktywności aktywów obliczono za pomocą ilorazu wartości przychodów ze sprzedaży oraz wartości aktywów, czyli przychody ze sprzedaży $\div$ aktywa. 
fazach - w fazie wprowadzenia (innowacyjności) produktu wskaźnik produktywności będzie niski, gdyż zdolności produkcyjne będą wykorzystywane tylko w niewielkim stopniu, co nie musi oznaczać, że korporacja źle zarządza aktywami. Natomiast kiedy produkt jest w szczytowym punkcie fazy dojrzałości, poziom sprzedaży stabilizuje się, a następnie spada, więc bezpośrednio wpływa to na poziom wskaźnika produktywności aktywów.

Wskaźnik produktywności aktywów, w latach 1996-2011, dla dziewięciu korporacji, które zostały objęte szczegółowymi badaniami, wahał się od 0,1 do 2,5 (tab. 2, ryc. 8). Najwyższą produktywnością zgromadzonego majątku charakteryzowała się korporacja Amazon.com, która w większości lat objętych badaniami odznaczała się najwyższymi wartościami wskaźnika, wahającymi się od 0,7 do 2,5. Wśród korporacji o najwyższej produktywności aktywów znajdowały się również Nokia oraz Apple. Natomiast najniższą produktywnością odznaczała się korporacja Microsoft, dla której wartości wskaźnika wahały się od 0,9 do 0,4. Należy także zaznaczyć, że dla korporacji Apple oraz Ericsson na początku badanego okresu obserwowano najwyższe wartości wskaźnika, zaś w miarę upływu czasu jego wartości były coraz niższe. Zatem posiadane aktywa były najlepiej wykorzystywane przez Amazon.com, Nokię i Apple, przy czym Amazon.com w miarę upływu czasu poprawiał efektywność wykorzystania majątku. Nokia charakteryzowała się stabilizacją pod tym względem, zaś Apple w coraz mniejszym stopniu wykorzystywał swoje aktywa.

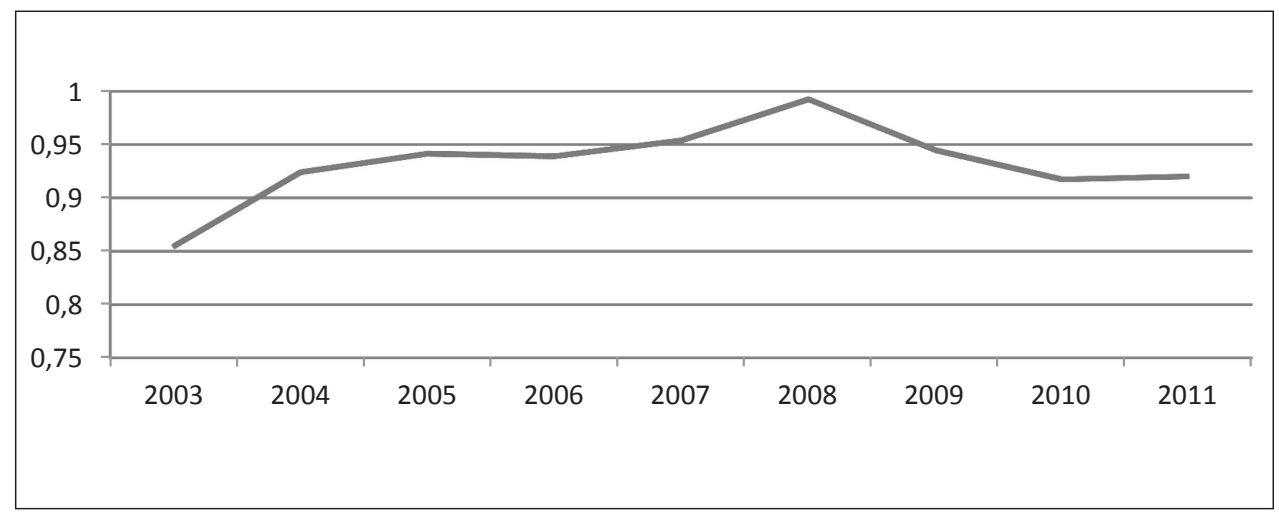

Ryc. 7. Zmiany wskaźnika produktywności aktywów dominujących korporacji informatycznych w latach 2003-2011

Źródło: opracowanie własne na podstawie raportów rocznych badanych korporacji 
Tab. 2. Wskaźnik produktywności aktywów analizowanych korporacji informatycznych w latach 1996-2011

\begin{tabular}{|c|c|c|c|c|c|c|c|c|c|}
\hline Lata & Google & Apple & Ericsson & $\begin{array}{c}\text { Amazon. } \\
\text { com }\end{array}$ & IBM & Microsoft & Nokia & Motorola & Panasonic \\
\hline 1996 & & 1,8 & 1,5 & 1,9 & 0,9 & 0,9 & 1,2 & & 1,0 \\
\hline 1997 & & 1,7 & 1,3 & 1,0 & 1,0 & 0,8 & 1,3 & & 0,9 \\
\hline 1998 & & 1,4 & 1,2 & 0,9 & 0,9 & 0,6 & 1,3 & & 0,9 \\
\hline 1999 & & 1,2 & 1,3 & 0,7 & 1,0 & 0,5 & 1,4 & & 1,0 \\
\hline 2000 & & 1,2 & 1,0 & 1,3 & 1,0 & 0,4 & 1,5 & 0,1 & 1,0 \\
\hline 2001 & 1,0 & 0,9 & 0,9 & 1,9 & 1,0 & 0,4 & 1,4 & 0,9 & 0,8 \\
\hline 2002 & 1,5 & 0,9 & 0,7 & 2,0 & 0,8 & 0,4 & 1,3 & 0,9 & 0,9 \\
\hline 2003 & 1,7 & 0,9 & 0,6 & 2,4 & 0,9 & 0,4 & 1,3 & 0,8 & 1,0 \\
\hline 2004 & 1,0 & 1,0 & 0,7 & 2,1 & 0,9 & 0,6 & 1,3 & 1,0 & 1,1 \\
\hline 2005 & 0,6 & 1,2 & 0,7 & 2,3 & 0,9 & 0,6 & 1,6 & 1,0 & 1,1 \\
\hline 2006 & 0,6 & 1,1 & 0,8 & 2,5 & 0,9 & 0,7 & 1,9 & 1,1 & 1,1 \\
\hline 2007 & 0,7 & 0,9 & 0,8 & 2,3 & 0,8 & 0,9 & 1,4 & 1,1 & 1,2 \\
\hline 2008 & 0,7 & 0,8 & 0,7 & 2,3 & 0,9 & 0,9 & 1,4 & 1,1 & 1,3 \\
\hline 2009 & 0,6 & 0,9 & 0,8 & 1,8 & 0,9 & 0,7 & 1,2 & 0,9 & 1,3 \\
\hline 2010 & 0,5 & 0,9 & 0,8 & 1,8 & 0,9 & 0,7 & 1,1 & 0,9 & 0,9 \\
\hline 2011 & 0,5 & 0,9 & 0,8 & 1,9 & 0,9 & 0,6 & 1,1 & 0,9 & 1,2 \\
\hline
\end{tabular}

Źródło: obliczenia własne

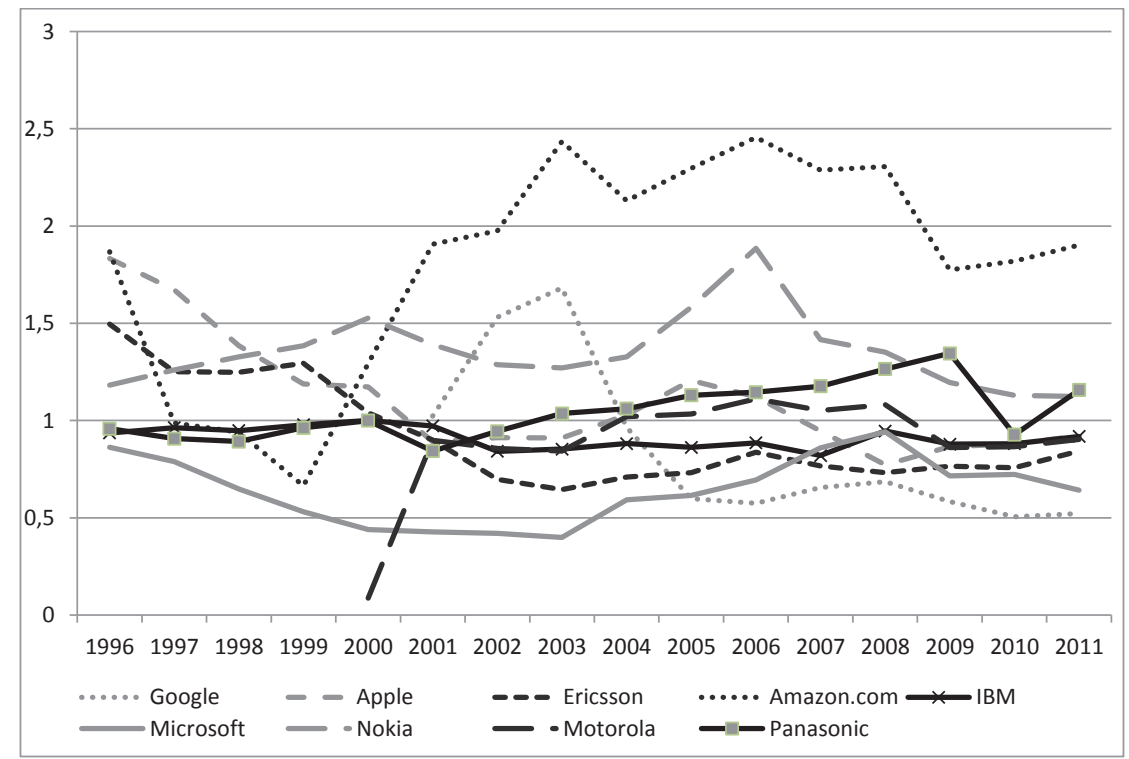

Ryc. 8. Zmiany wartości wskaźnika produktywności aktywów analizowanych korporacji informatycznych w latach 1996-2011

Źródło: opracowanie własne na podstawie raportów rocznych badanych korporacji 


\section{Podsumowanie}

Z przedstawionej analizy wynika, że najbardziej dynamicznym okresem w rozwoju korporacji był czas od lat 90. XX wieku do 2007 roku, kiedy następowało wkraczanie społeczeństwa w informacyjną fazę rozwoju. Wówczas pojawiły się bowiem najbardziej chłonne rynki na oferowane produkty. Ważnymi czynnikami sprzyjającymi wzrostowi zagranicznej aktywności korporacji oraz zwiększającymi możliwości ich działania okazały się: nowa rewolucja technologiczna, w tym szczególnie dynamiczny rozwój sektora technologii informacyjnych, diametralne zmiany w branży telekomunikacyjnej oraz upowszechnienie internetu. Dlatego w ostatnim dziesięcioleciu obserwowany jest wzrost inwestycji w branże zaawansowane technologicznie, czyli komputery i wyroby elektroniczne, ale również w farmaceutyki, biotechnologię, samochody, sprzęt RTV i AGD oraz w towary szybko zbywalne.

Badania wskazują, że poszczególne korporacje informatyczne cechowały się w analizowanym okresie różnymi tendencjami zmian potencjału ekonomicznego. Na ten proces miało wpływ wiele czynników, m.in. sytuacje kryzysowe, które zaznaczyły się zarówno na początku stulecia - tzw. pęknięcie bańki internetowej, jak i w ostatnich latach z powodu światowego kryzysu gospodarczego.

Kolejne lata kształtowania się badanych korporacji, ze względu na okres kryzysu i jego skutki, były dla nich trudne i wymagały intensywnych działań, których rezultaty jednym pozwoliły szybko poradzić sobie z niekorzystną sytuacją, a dla innych były niewystarczające, dlatego dotychczas odczuwają one skutki tego załamania.

\section{Literatura \\ Referenes}

Dorocki, S. (2010). Współczesne procesy internacjonalizacji produkcji i delokalizacji przemysłu samochodowego Francji. Prace Komisji Geografii Przemystu Polskiego Towarzystwa Geograficznego, $16,125-136$.

Kilar, W. (2009a). Zróżnicowanie potencjału ekonomicznego światowych korporacji informatycznych. Prace Komisji Geografii Przemystu Polskiego Towarzystwa Geograficznego, 13, 110-121.

Kilar, W. (2009b). Rola korporacji Apple w kształtowaniu społeczeństwa informacyjnego. Przedsiębiorczość - Edukacja, 5, 48-56.

Kilar, W. (2010). Procesy kształtowania się korporacji Ericsson. Prace Komisji Geografii Przemystu Polskiego Towarzystwa Geograficznego, 16, 153-168.

Kilar, W. (2011). Wpływ kryzysu na funkcjonowanie korporacji Panasonic. Prace Komisji Geografii Przemystu Polskiego Towarzystwa Geograficznego, 17, 187-196.

Kilar, W. (2012). Funkcjonowanie korporacji Amazon.com w warunkach kryzysu gospodarczego. Referat podczas 9 Międzynarodowej Konferencji Naukowej pt. „Przedsiębiorczość w warunkach kryzysu gospodarczego” połączonej z 5 Ogólnopolskim Zjazdem Nauczycieli Przedsiębiorczości. Kraków, 8-9 października 2012 r.

Kilar, W. (2014). Spatial Concentration of IT Corporation Headquarters. Prace Komisji Geografii Przemystu Polskiego Towarzystwa Geograficznego, 25, 56-80.

Zioło, Z. (2009). Procesy kształtowania się światowych korporacji i ich wpływ na otoczenie. Prace Komisji Geografii Przemystu Polskiego Towarzystwa Geograficznego, 12, 11-32. 
Wioletta Kilar, dr, Uniwersytet Pedagogiczny im. Komisji Edukacji Narodowej w Krakowie, Instytut Geografii, Zakład Przedsiębiorczości i Gospodarki Przestrzennej. Geograf ekonomiczny. Adiunkt w Zakładzie Przedsiębiorczości i Gospodarki Przestrzennej Instytutu Geografii Uniwersytetu Pedagogicznego w Krakowie. Jej zainteresowania badawcze ukierunkowane są przede wszystkim na procesy kształtowania się i funkcjonowania ponadnarodowych korporacji, globalizacji, przemian struktur przestrzennych przemysłu oraz problematykę nauczania przedsiębiorczości i geografii w szkole.

Wioletta Kilar, Ph.D., the Pedagogical University of Cracow, Institute of Geography, the Department of Entrepreneurship and Spatial Management. She is an economic geographer. She is currently employed as an assistant professor in the Department of Entrepreneurship and Spatial Management in the Institute of Geography at the Pedagogical University of Cracow. Her research interests focus primarily on the processes of formation and operation of multinational corporations; globalization; transformation of spatial structures of industry; and issues of teaching entrepreneurship and geography in schools.

\section{Adres/address:}

Uniwersytet Pedagogiczny

Instytut Geografii

Zakład Przedsiębiorczości i Gospodarki Przestrzennej

ul. Podchorążych 2, 30-084 Kraków, Polska

e-mail:W.Kilar@up.krakow.pl 